\title{
海绵城市理念在市政给排水设计中的有效运用
}

靳亚轻

福海县金源城市开发建设有限公司

DOI:10.32629/hwr.v3i8.2332

[摘 要] 在全面贯彻可持续发展理念的影响下, 海绵城市理念成为社会各界关注的焦点。海绵城市理念在市政给排水设计中 的应用,充分起到了优化水资源分配,提高水资源综合利用率的目的。基于此,本文论述了海绵城市的基本概念,海绵城市理念在 市政给排水设计中的应用价值, 以及市政给排水设计的主要内容,并在此基础上提出了切实可行的应用策略,旨在促进城市经 济建设与生态文明建设的协同进步。

[关键词] 海绵城市理念; 市政给排水设计; 应用策略

如今, 我国城市发生了翻天覆地的变化, 高楼大厦拔地 而起, 道路桥梁工程数量及规模不断扩张, 以此更好的满足 了城市居民的多元化需求。与此同时, 淡水资源供应贵乏, 而水生态环境污染成为制约可持续发展的主要因素。海绵城 市理念, 使人们客观认知到优化水资源分配, 实现水资源循 环利用的深刻含义。为此, 全面探究海绵城市理念在市政给 排水设计中的应用具有重要意义。

\section{1 海绵城市的基本概念}

所谓海绵城市, 是指将城市改造成 “海绵体”, 在应对自 然灾害或生态环境突变时, 能够充分发挥弹性作用。例如, 在持续强降雨情况下, 可以实现吸水、蓄水、渗水与净水, 在干旱季节, 释放蓄存的水资源, 用于农业灌溉或绿化灌溉, 增大水资源的综合利用率。在建设海绵城市的过程中, 要遵 循生态优先的基本原则, 注重自然途径与人工措施的有机整 合, 在保证城市防洪排涝安全的基础上, 做到城市内部空间 雨水的渗透、蓄积与净化, 进而实现雨水的循环利用, 减轻水 资源供应压力, 维系生态系统平衡。与此同时, 还需统筹地表 水、地下水和自然降水等水资源, 优化给排水循环系统, 全面 发挥海绵城市的优势效能。

\section{2 海绵城市理念在市政给排水设计中的应用价值}

2.1 实现雨水的循环利用, 提高资源利用效率

雨水是水资源体系的重要组成部分。传统的市政道路给 排水系统, 对于雨水的回收利用率较低, 进而造成大量的水 资源浪费, 这也在一定程度上加重了城市内部空间非硬化区 域的排渗压力。如果采用行之有效的技术手段, 做到雨水资 源的循环利用, 则可以提高水资源的综合利用率, 减轻水资 源的供应压力。而海绵城市理念, 则可做到雨水资源的循环 利用, 协调解决水资源过度浪费问题, 改善水资源供应现状。 与此同时, 建设海绵城市也有助于缓解雨水对生产生活的影 响, 改善城市居民的生活品质, 提升人们的幸福指数。

\section{2改善生态环境品质, 维系生态系统平衡}

伴随市场经济的繁荣发展与可持续发展理念的深化落 实, 人们的物质文化生活水平不断提高, 环保意识也进一步 增强。由此, 生态环境污染问题成为社会各界关注的焦点。
在这样的大环境背景下, 市政给排水设计应当注重海绵城市 理念, 在改善生态环境品质, 维系生态系统平衡的基础上, 提 升生活质量等级。现阶段, 我国相继制定并出台了一系列关 于生态环境保护的法律条例, 其中, 建设海绵城市就是最具 代表性的政策之一。总而言之, 建设海绵城市有助于改善生 态环境品质, 为城市居民营造宜居的生活空间。

\section{3 市政给排水设计的主要内容}

市政给排水设计主要包括给水系统设计与排水系统设 计两部分, 只有进一步明确给水与排水系统设计的主体内容, 才能加强整体设计的合理性。下面, 笔者就将对市政给排水 设计的主要内容进行说明。

\section{1 给水系统设计的关键内容}

在市政给水系统设计过程中, 首要前提是充分考虑区域 自然环境特征, 如地质结构条件、地下水文条件及气候环境 条件, 淡水资源分布情况、地下水位差及降水量等。尽可能 的在降水量较大的季节安排耗水量大的工程项目, 在降水量 较小的季节安排耗水量小的工程项目。此外, 根据区域的水 资源分配情况, 优化资源配置, 保证给水系统的科学合理性, 从而满足区域经济建设与生态文明建设的基本需求。

3.2 排水系统设计的关键内容

在市政排水系统设计过程中, 要综合考量如下几方面 内容:

3.2.1制定完整且合理的防洪排涝方案。在排水系统设 计前, 结合区域实际情况, 采集设计工作所需的文献资料, 严 格遵照工程项目的基本要求与排洪标准, 加强规划设计的科 学合理性。

3.2.2注重污水处理的时效性与合理性。在排水系统设 计时, 根据城市的空间布局与排污标准, 制定完整的设计方 案。同时, 积极推广应用节能环保原材料, 提高排污系统运行 效率, 保证生态效益最大化。

3.2. 3 掌握污水排放量。采用科学合理的计算手段, 明确 各区域、各时段的污水排放量, 为优化排污系统设计提供可 靠的参考依据。

4 将海绵城市理念融合到市政给排水设计中的应用策略 
随着可持续发展理念的深化落实, 将海绵城市理念融合 到市政给排水设计中已成为必然趋势。为此, 基于海绵城市 理念的市政给排水设计, 应当与城市长期规划发展相协调; 加大专项技术研发力度; 注重顶层设计工作; 明确体系建设 责权划分, 优化市政给排水设计, 进而充分发挥出海绵城市 的优势效能。

4.1 与城市长期规划发展相协调

将海绵城市理念融合到市政给排水系统设计中, 需要注 重海绵城市的高弹性特征, 并与城市规划建设协调配合。具 体措施如下所述:

在市政给排水设计过程中, 综合考量城市的未来发展规 划, 通过规划预留或优先设计的方式为城市的良好发展奠定 坚实基础, 从而确保城市给排水系统为城市居民提供优质服 务, 促进城市经济建设与生态文明建设的协同进步, 达到可 持续发展战略目标。

4. 2 加大专业技术研发力度

在城市规划建设进程中, 市政给排水系统发挥着至关重 要的作用。给排水系统设计与建设是一项综合性、专业性极 强的工作, 具有涉及面广、周期长且投资数额大等特征。基 于此, 在市政给排水系统设计与建设过程中, 要进一步明确 各方面基本要求。

此外, 我国海绵城市起步建设时间较晚, 与西方发达国 家相比, 仍处于初期阶段。在实际建设过程中, 缺乏丰富的经 验作为指导, 进而导致建设工作存在诸多亟待解决的突出性 问题。对此, 相关人员需加大对专业性技术研究工作的重视 力度, 加强对海绵城市理念在市政给排水设计中的应用研究, 依托新材料、新工艺与新技术, 为市政给排水系统建设夯实 基础。

4. 3 注重顶层设计工作

在海绵城市建设过程中, 需要投入大量的时间, 充足的 资源与高额的资金。目前, 我国海绵城市建设仅仅停留在初 期探索阶段, 并不具备丰富的建设经验, 为此, 我们需要秉承 与时俱进的基本原则, 积极借鉴西方发达国家的先进经验, 从根本上提升整体设计水平。

从国家宏观发展角度来说, 海绵城市建设需要制定完整 的建设方案, 以实现雨水资源的循环利用, 促使海绵城市的 发展达到预期水平。迄今为止, 我国已选择了 30 个城市作为 海绵城市建设试点对象, 旨在客观分析建设环节存在的各类 突出性问题, 不断总结实践经验, 为实现海绵城市理念与市
政给排水设计的有机整合提供有价值的参考意见。

随着时代的发展与社会文明的进步,科技水平会越来越 高, 实践经验也会越来越丰富, 再加上国家宏观政策的扶持 与助力, 相信海绵城市理念在市政给排水设计中的应用将会 日趋成熟化。由此, 一方面提升水资源综合利用率, 另一方面 为人们提供舒适、健康且安全的生活环境, 推动城市的良好 发展。

4. 4 明确划分体系建设的相关责任

伴随市场经济体制的深化变革与社会产业结构的优化 调整, 我国城市发展已进入关键转折期。为进一步推动城市 的良好发展, 应当践行科学发展观念, 全面落实城市建设工 作。而市政给排水系统作为城市最重要的基础设施, 有效优 化给排水系统设计具有实际意义。

在给排水设计过程中, 要着重注意如下几方面内容: 其 一, 政府部门要充分发挥宏观调控作用, 做好分析、规划与 统筹工作, 保证给排水设施的安全性; 其二, 相关部门需加 大监督管理力度, 根据工程市场概况与规章条例, 严格把控 招投标工作, 加快海绵城市建设速度; 其三, 积极鼓励相关 企业与科研机构, 注重海绵城市理念应用环节的技术研发 工作, 不断总结实践经验, 为市政给排水设计提供有价值的 参考信息。

\section{5 结束语}

综上所述我们可以获知, 海绵城市理念在市政给排水设 计中的应用, 不仅有助于优化水资源配置, 增大水资源的综 合利用率, 而且还能改善生态环境品质, 维系生态系统的平 衡, 最终促进经济建设与生态文明建设的协同进步, 为构建 特色主义文明城市奠定坚实基础, 并最终实现可持续发展的 战略目标。

[参考文献]

[1]徐锋.分析海绵城市理念在市政给排水设计中的运 用[J].科学技术创新,2017,(8):214.

[2]付昊.海绵城市理念在市政给排水设计中的运用 [J]. 江西建材,2017,(24):50-51.

[3]林进南.海绵城市理念在市政给排水设计中的运用 [J].智能城市,2018,4(5):22-23.

[4]郑对霞.海绵城市理念在市政排水设计中的应用实践 [J].资源节约与环保,2018,199(6):67+69.

[5]段晓星.海绵城市理念在市政排水设计中的应用实践 分析[J].绿色环保建材,2018,(4):84. 